\title{
Produktivitas Rumput Hamil (Panicum maximum cv Hamil) yang Ditanam Menggunakan Benih Berbeda
}

\section{(Productivity of Hamil Grass (Panicum maximum cv Hami) Planted Using Different Seeds)}

\author{
Achmad Fanindi*, Endang Sutedi, Harmini Harmini
}

(Diterima Juli 2020/Disetujui Juli 2021)

\begin{abstract}
ABSTRAK
Sifat reproduksi sangat menentukan metode seleksi yang akan diterapkan pada pemuliaan tanaman. Rumput benggala kultivar Hamil diduga bersifat apomiksis sehingga perlu diteliti untuk mendeskripsikan sifat reproduksi tanaman tersebut. Langkah penelitian dimulai dengan mengamati karakter morfologi, dilanjutkan dengan fase generative dan produksi biji kultivar tersebut yang ditanam menggunakan biji (generatif) dan pols (vegetatif) di rumah kaca Balai Penelitian Ternak Ciawi. Percobaan menggunakan Rancangan Acak Lengkap dengan 10 ulangan, dan sebagai perlakuan adalah dua jenis benih, yaitu dari biji dan pols. Benih kultivar Hamil diambil dari kebun Koleksi Balitnak, ditanam dalam pot berdiameter $40 \mathrm{~cm}$ dan tinggi $30 \mathrm{~cm}$, menggunakan media tanah dari kebun percobaan Balitnak Ciawi. Hasilnya menunjukkan bahwa sebagian besar karakter morfologi kultivar yang ditanam menggunakan biji dan pols tidak berbeda $(P>0,05)$ sehingga diduga sifatnya apomiksis. Perbedaan morfologi hanya terletak pada panjang dan lebar daun bendera serta panjang ruas; kultivar yang ditanam dari biji lebih tinggi. Produksi biji, bobot biji bernas, dan daya kecambah biji pada kultivar yang ditanam dari biji lebih tinggi $(P<0,05)$ dibandingkan dengan kultivar yang ditanam dari pols. Penelitian lanjutan masih diperlukan untuk mengetahui sifat apomiksis pada kultivar Hamil secara sitologi.
\end{abstract}

Kata kunci: apomiksis, benih, morfologi, rumput benggala

\section{ABSTRACT}

Reproductive traits determine the selection method in plant breeding. The benggala grass of the Hamil cultivar was thought to be apomictic; thus, a study was conducted to determine its reproduction. The research began by studying the morphological characters, continued with observing the generative phase and seed production of the cultivar planted from seeds (generative) and from pols (vegetative). The experiment was conducted in the greenhouse of the Research Institute of Animal Production. The experimental design was a completely randomized design with ten replications, and the treatments were different types of plant materials: seeds and pols. The Hamil cultivar taken from RIAP Collection was planted in pots with a diameter of $40 \mathrm{~cm}$ and a height of $30 \mathrm{~cm}$. The results showed that most of the morphological characters of the Hamil cultivar planted from seeds and from pols were not different $(P$ $>0.05$ ), so it was presumed that they were apomictic. The difference in morphology was only in the length and width of the flag leaves and the length of the internodes, where the cultivars planted using seeds were higher. The production of seeds, pithy seed weight, and seed germination of cultivars planted using seeds were higher (P<0.05). Further research is needed to determine the apomixis properties based on cytologically Hamil cultivars.

Keywords: apomixis, benggala grass, morphology, plnting material; seed

\section{PENDAHULUAN}

Rumput benggala merupakan rumput yang dikenal oleh peternak di Indonesia dan telah banyak digunakan sebagai pakan ruminansia. Rumput ini merupakan tanaman pakan yang penting di daerah tropis maupun semi tropis, tumbuh baik pada kondisi tanah yang sedang sampai subur, serta irigasi yang baik. Rumput benggala memiliki keunggulan berupa jumlah anakan yang banyak, siklus produksi pendek, palatabilitas yang baik, dan biomassa tinggi (Ramakrishnan et al. 2014). Produksi rumput benggala berkisar antara 13,8

Balai Penelitian Ternak, Jl. Veteran III Ciawi Tapos, Desa. Banjarwaru, Kec. Ciawi, Bogor 16720

* Penulis Korespondensi: Email: afanindi@gmail.com dan $21,4 \mathrm{t} /$ ha/tahun bahan kering (BK), produksinya lebih rendah jika dibandingkan rumput gajah, tetapi memiliki persentase bobot daun yang lebih tinggi $(51,7-71,5 \%)$ daripada rumput gajah $(48,3 \%)$ (Jank et al. 2013). Kapasitas tampung rumput benggala di padang penggembalaan adalah 2,9-5,5 satuan ternak/ha, dengan rata rata pertambahan bobot badan harian $0,65-0,80 \mathrm{~kg} / \mathrm{ekor} / \mathrm{hari}$ dan pertambahan bobot hidup 213-554 kg/ha (Alvarenga et al. 2020). Dari segi nutrisi, rumput ini mengandung protein kasar (PK) $5,1-10,6 \%$, acid detergent fiber (ADF) 34,6-39,7\% dan neutral detergent fiber (NDF) 62,3-66,6\% (Hare et al. 2013).

Rumput benggala kultivar Hamil berasal dari benih kebun rumput Mr. Jack Hamil di Daintree, Queensland utara pada tahun 1935. Namun, tidak ada sumber asli 
benih ini, sampai pada tahun 1956, rumput ini dinamakan kultivar Hamil, merujuk pada orang yang memelopori asal dari bibit rumput ini (Clements \& Henzell 2010). Rumput kultivar tersebut memiliki tinggi 2,4-3,0 m, lebih kuat dan lebih kasar jika dibandingkan rumput benggala komersial. Daun berwarna hijau kebiruan, lebar, pipih, panjang, dan runcing. Pembungaannya berupa malai yang besar dan terbuka dengan cabang bawah cenderung melingkar (Atherton 1963). Hampir sebagian besar rumput benggala lokal yang tumbuh banyak di Indonesia adalah kultivar Hamil karena terdapat kesesuaian morfologi dengan rumput benggala kultivar Hamil.

Reproduksi rumput benggala sebagian besar adalah apomiksis, termasuk kultivar Hamil. Apomiksis merupakan cara reproduksi yang khas, melalui meiosis untuk menghasilkan benih yang secara genetik akan sama dengan induknya, atau sering juga disebut sebagai reproduksi klonal melalui biji (Kaushal et al. 2018). Apomiksis diharapkan dapat menjanjikan manfaat ekonomi lebih dari revolusi hijau, dengan memperbaiki tanaman $\mathrm{F} 1$ sebagai varietas di bidang tanaman. Fenomena apomiksis memperlihatkan regulasi genetik yang kompleks dan dikaitkan dengan genotipe, poliploidi, interaksi banyak gen, dan kondisi lingkungan (Hand \& Koltunow 2014; Conner \& OziasAkins 2017). Terdapat tiga komponen penting dalam ekspresi dan pembentukan bibji apomiksis, yaitu apomeiosis, partenogenesis, dan pseudogami; komponen-komponen ini yang akhirnya menghasilkan biji apomiksis (Ozias-Akins 2006). Hasil penelitian menunjukkan ada perbedaan pembentukan kalus antara apomiksis dan seksual dalam kultur jaringan yang dikembangkan dari daun rumput benggala (Chen et al. 2015). Perbedaan ini menjadi kajian yang menarik, apakah ada perbedaan morfologi antara rumput yang berasal dari benih seksual dan dari benih apomiksis.

Selama ini di Indonesia masih belum banyak dipelajari reproduksi rumput benggala secara detail, termasuk benih yang dihasilkan, apakah berasal dari tanaman seksual atau apomiksis. Langkah awal pengamatan adalah mempelajari morfologi pada fase vegetatif dan generatif, serta produksi benih rumput benggala kultivar Hamil yang ditanam menggunakan biji (hasil generatif) dan pols (hasil vegetatif). Pengamatan morfologi pada rumput benggala yang ditanam menggunakan biji dan pols diharapkan memberi gambaran tentang rumput apomiksis atau seksual. Kecenderungan persamaan morfologi antara tanaman yang ditanam menggunakan biji dan pols dapat dijadikan indikasi adanya pembentukan biji yang tidak dipengaruhi oleh induk, walaupun perlu diuji lanjutan yang lebih mendalam. Selain itu penggunaan asal benih yang berbeda juga bertujuan mempelajari pengaruh perbedaan asal benih pada produksi benih yang dihasilkan.

\section{METODE PENELITIAN}

Penelitian di rumah kaca Balai Penelitian Ternak (Balitnak) Ciawi ini menggunakan pot berdiameter 40 $\mathrm{cm}$ dan tinggi $30 \mathrm{~cm}$, dengan media tanam adalah tanah Ciawi. Setelah tumbuh baik, tanaman dipupuk dengan pupuk buatan (urea $150 \mathrm{~kg} / \mathrm{ha}$, TSP $100 \mathrm{~kg} / \mathrm{ha}$, dan $\mathrm{KCl} 100 \mathrm{~kg} / \mathrm{ha}$ ) dan pupuk kandang (5 ton/ha). Tanah yang digunakan sebagai media tanam adalah tanah Ciawi, dengan komposisi dan karakteristik tanah yang meliputi pasir (27\%), debu (26\%), liat (47\%), $\mathrm{pH}$ 6,2, C/N 13, $\mathrm{P}_{2} \mathrm{O}_{5} 10,9, \mathrm{~K}_{2} \mathrm{O} 14,21$, Ca 13,03, Mg 3,87, K 2,79, kapasitas tukar kation (KTK) 11,89, dan kejenuhan basa $>100 \%$. Rata-rata kelembapan dan suhu rumah kaca selama penelitian berlangsung adalah $80,6 \%$ dan $28^{\circ} \mathrm{C}$.

Penelitian produktivitas rumput benggala menggunakan Rancangan Acak Lengkap, dengan 10 ulangan. Perlakuan dalam penelitian ini ialah dua macam asal bahan tanam, yaitu bahan tanam yang berasal dari pols (vegetatif) dan bahan tanam yang berasal dari biji (generatif). Tanaman yang digunakan adalah kultivar Hamil, yang telah dikoleksi dan dievaluasi oleh peneliti Agrostologi di Balitnak Ciawi. Parameter yang diamati adalah morfologi tanaman, sifat reproduksi, jumlah benih per malai (rataan dari 3 malai/rumpun), dan daya kecambah benih. Selain itu diamati juga kualitas hijauan.

\section{HASIL DAN PEMBAHASAN}

Karakter morfologi antara rumput benggala yang ditanam menggunakan biji dan pols menunjukkan bahwa karakter kualitatif seperti warna daun, tepi daun, warna buku, warna putik, warna kaki, dan karakter kuantitatif seperti tinggi tanaman, panjang daun, lebar daun, diameter batang, produksi benih, jumlah anakan antara rumput benggala kultivar Hamil yang ditanam menggunakan biji dan pols tidak berbeda (Tabel 1). Sifat tumbuh tanaman yang berasal dari biji terkategori semi-erect karena memiliki sudut yang hampir sama, yaitu $22^{\circ}$ (UPOV 2006). Warna helai daun kultivar Hamil yang ditanam baik dari biji maupun pols juga tidak berbeda, yaitu berwarna hijau tua. Warna ini sesuai dengan warna daun pada kultivar Hamil yang berwarna hijau kebiruan (hijau tua) (Walsh 1959). Tekstur permukaan daun, tepi daun, dan warna tepi daun kultivar Hamil yang ditanam dari biji dan pols juga tidak berbeda, berturut-turut menunjukkan agak tekstur kasar, kasar, dan putih. Tekstur batang dan buku kultivar yang ditanam menggunakan biji dan pols juga tidak berbeda, begitupun dengan warna buku, warna putik, dan warna kaki, berturut-turut adalah hijau, ungu muda, dan hijau keunguan. Tidak adanya perbedaan pada parameter kualitatif ini diduga karena gen yang 
mengendalikan parameter kualitatif biasanya adalah satu atau dua gen yang dominan (Tabel 2).

Peubah kuantitatif kultivar Hamil yang dipengaruhi oleh bahan tanam biji dan pols adalah panjang dan lebar daun bendera $(P<0,05)$ (Tabel 1$)$. Tanaman yang berasal dari biji memiliki daun bendera yang lebih panjang dan lebih lebar jika dibandingkan dengan yang ditanam menggunakan pols. Hasil penelitian Al-Tahir (2014) menunjukkan bahwa terdapat hubungan positif antara luas daun bendera, bobot daun bendera, kandungan klorofil dan produksi padi, gandum, dan oat. Daun bendera pada tanaman sereal seperti padi merupakan organ yang penting; daun ini merupakan daun yang tumbuh terakhir. Pada saat pembuahan, daun memasok nutrisi ke benih untuk perkembangannya. Saat benih matang, daun bendera biasanya tidak layu sehingga selama proses pembentukan benih, daun bendera dapat menyediakan lebih dari setengah nutrisi yang dibutuhkan guna pengembangan benih padi (Ali et al. 2010). Selain itu, daun bendera secara fisik lebih dekat dengan benih dan keberadaannya lebih lama dibandingkan daun lainnya. Penelitian lain juga menunjukkan bahwa terdapat hubungan antara sifat kuantitatif daun bendera dan hasil, serta terdapat lebih dari $20 \%$ metabolit pada daun bendera secara nyata berkorelasi dengan metabolit yang sama dalam perkembangan (Hu et al. 2020).
Asal benih juga berpengaruh nyata $(P<0,05)$ pada panjang ruas kultivar Hamil. Tanaman yang berasal menggunakan biji memiliki panjang ruas yang lebih pendek jika dibandingkan dengan yang berasal dari pols. Panjang ruas berhubungan erat dengan tinggi tanaman; semakin pendek ruas, tanaman juga semakin pendek. Panjang ruas juga merupakan unsur penting untuk seleksi varietas tahan rebah, terutama pada ruas bawah yang pendek (Madic et al. 2016). Ruas yang lebih panjang pada kultivar yang berasal dari pols berbanding lurus dengan tinggi tanamannya, artinya, tinggi tanaman cenderung lebih tinggi jika dibandingkan tanaman yang berasal dari biji (Tabel 1).

Karakter morfologi selain panjang ruas, panjang dan lebar daun bendera tidak menunjukkan perbedaan yang nyata $(P>0,05)$ antara kultivar yang ditanam baik dari biji maupun dari pols. Hal ini memperlihatkan bahwa sebagian besar karakter kuantitatif kultivar yang ditanam menggunakan pols dan biji hampir sama. Kondisi ini mungkin berhubungan dengan sifat reproduksi apomiksis pada kultivar Hamil, yaitu akan menghasilkan biji yang secara genetik akan sama dengan induknya (Kaushal et al. 2018).

Produksi dan bobot biji kultivar Hamil yang ditanam dari biji lebih tinggi $(P<0,05)$ jika dibandingkan dengan yang ditanam dari pols (Gambar 1). Produksi dan bobot biji yang lebih tinggi pada kultivar ini diduga

Tabel 1 Rataan karakter kuantitatif kultivar rumput benggala kultivar Hamil (Panicum maximum cv Hamil) yang menggunakan bahan tanam dari biji sebelum dipotong

\begin{tabular}{|c|c|c|}
\hline \multirow{2}{*}{ Karakteristik } & \multicolumn{2}{|c|}{ Kultivar Hamil } \\
\hline & Biji & Pols \\
\hline Sifat tumbuh & Tegak $\left(22,6^{\circ}\right)$ & Tegak $\left(22,5^{\circ}\right)$ \\
\hline Tinggi tanaman $(\mathrm{cm})$ & $188,4 \pm 9,72$ & $195,8 \pm 13,59$ \\
\hline $\begin{array}{l}\text { Tinggi tanaman saat muncul kuntum bunga } \\
(\mathrm{cm})\end{array}$ & $150,1 \pm 14,95$ & $136,1 \pm 25,80$ \\
\hline Panjang daun bendera (cm) & $32,4 a \pm 4,43$ & $24,2 b \pm 8,16$ \\
\hline Lebar daun bendera $(\mathrm{cm})$ & $2,5 a \pm 0,25$ & $1,9 b \pm 0,65$ \\
\hline Panjang batang terpanjang $(\mathrm{cm})$ & $212,1 \pm 12,90$ & $202,9 \pm 34,86$ \\
\hline Panjang kuntum bunga (cm) & $49,5 \pm 5,61$ & $53,3 \pm 12,59$ \\
\hline Jumlah spikelet (buah) & $24,4 \pm 2,55$ & $23,4 \pm 3,89$ \\
\hline Lebar daun $(\mathrm{cm})$ & $3,4 \pm 0,21$ & $3,2 \pm 0,48$ \\
\hline Jumlah anakan & $17,2 \pm 2,25$ & $16,6 \pm 2,72$ \\
\hline Diameter batang (mm) & $0,33 \pm 0,05$ & $0,33 \pm 0,11$ \\
\hline Lebar batas buku (cm) & $0,30 \pm 0,30$ & $0,28 \pm 0,03$ \\
\hline Panjang ruas $(\mathrm{cm})$ & $20,03 b \pm 3,89$ & $23,4 a \pm 3,86$ \\
\hline
\end{tabular}

Keterangan: Angka yang diikuti huruf yang berbeda pada baris yang sama menunjukkan perbedaan yang nyata menggunakan uji Tukey $5 \%$.

Tabel 2 Karakter kualitatif rumput benggala yang ditanam menggunakan benih yang berbeda

\begin{tabular}{lll}
\hline \multicolumn{1}{c}{ Karakteristik } & \multicolumn{1}{c}{ Biji } & Kultivar Hamil \\
\cline { 2 - 3 } Warna daun & Hijau tua & Hijau tua \\
Tekstur permukaan daun & Agak kasar & Agak kasar \\
Tepi daun & kasar & kasar \\
Warna tepi daun & putih & putih \\
Tekstur batang & berbulu & berbulu \\
Warna buku & hijau & hijau \\
Tekstur batas buku & berbulu & berbulu \\
Warna putik & Ungu muda & Ungu muda \\
Warna kaki & Hijau Keunguan & Hijau Keunguan \\
\hline
\end{tabular}



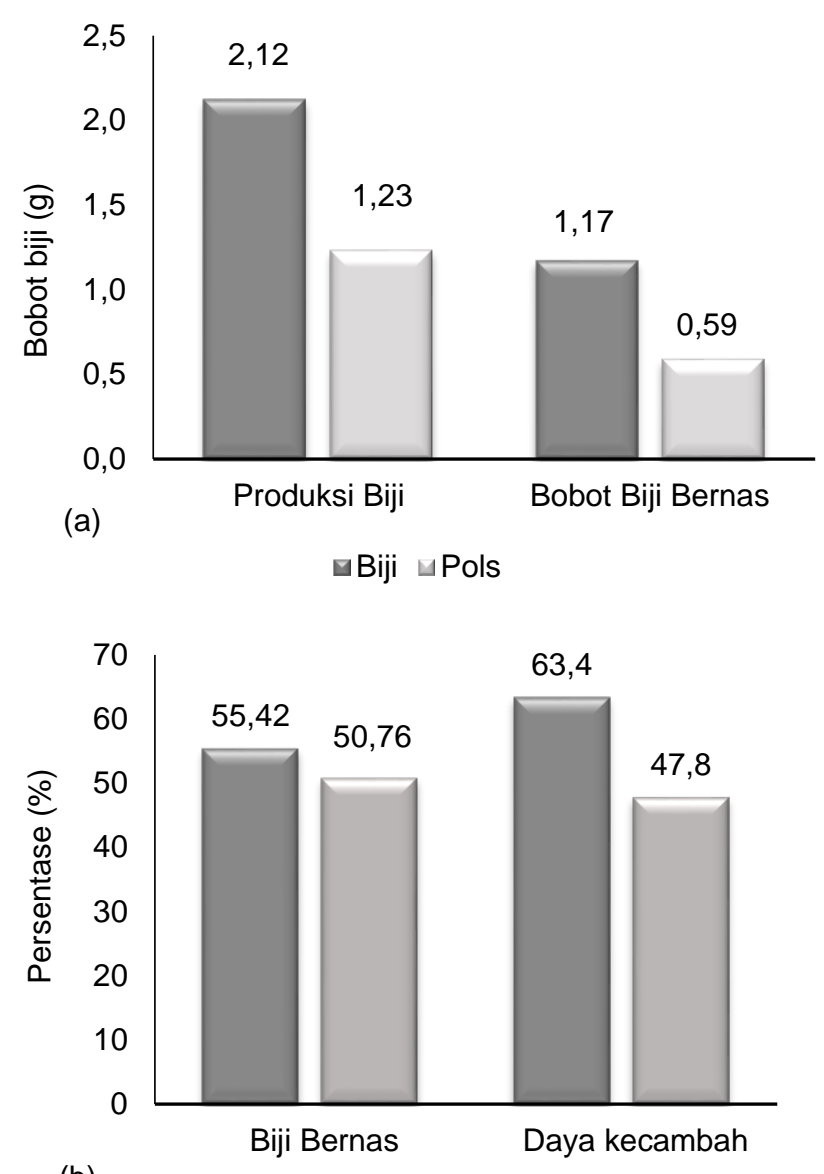

(b)

$$
\square \text { Biji } \square \text { Pols }
$$

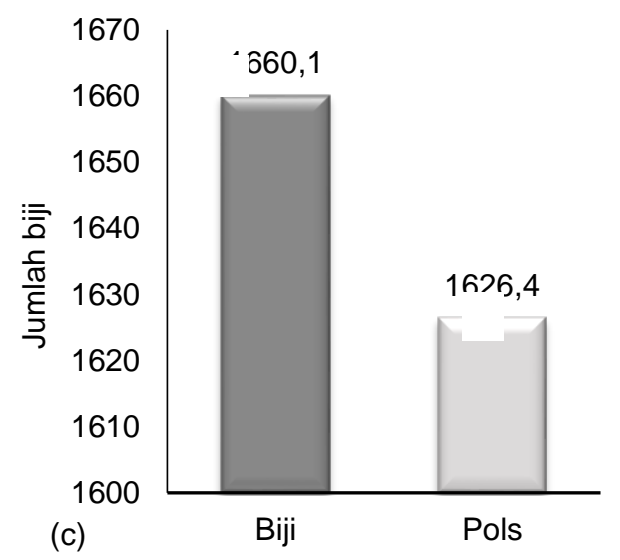

Gambar 1 Produksi biji, bobot biji. a) Persentase biji bernas, b) Persentase daya kecambah, dan c) Jumlah biji kultivar Hamil yang ditanam menggunakan biji dan pols.

berhubungan dengan panjang dan lebar daun bendera yang lebih tinggi (Tabel 1). Terdapat hubungan positif yang nyata antara daun bendera dan bobot biji pada padi, bahkan pemotongan daun bendera pada saat muncul malai akan berakibat menurunnya bobot-100 biji, berkurangnya panjang dan cabang malai, dan menurunnya produksi padi secara keseluruhan (Rahman et al. 2014). Daun bendera juga berpengaruh pada daya kecambah biji gandum (Heidari 2017). Daya kecambah biji kultivar Hamil yang ditanam dari biji lebih tinggi dibandingkan dengan kultivar yang menggunakan pols. Hal ini juga diduga berhubungan dengan panjang dan lebar daun bendera yang lebih tinggi pada kultivar yang ditanam dari biji jika dibandingkan dengan kultivar yang ditanam dari pols. Daya kecambah biji kultivar Hamil adalah 47-63\%, sementara daya kecambah biji rumput benggala yang disimpan dalam cool room selama 1-3 tahun adalah 43-63\% (Hare et al. 2018). Selain itu bobot biji bernas pada kultivar Hamil yang ditanam dari biji juga lebih tinggi $(P<0,05)$ jika dibandingkan dengan yang ditanam dari pols (Gambar 1).

Umur bunting, mulai berbunga, berbunga sempurna pada kultivar Hamil yang berasal dari biji nyata $(P$ $<0,05)$ lebih lama daripada yang berasal dari pols, sedangkan umur tanaman saat biji masak tidak dipengaruhi oleh asal benih yang ditanam. Umur berbunga sangat memengaruhi hasil panen dan kualitas buah (Cho et al. 2017). Selain itu, terdapat hubungan antara waktu berbunga dan produksi biji pada tanaman lentil, tetapi hubungannya bersifat negatif (Tambal et al. 2000), artinya, tanaman lentil yang waktu berbunganya lebih cepat akan memproduksi biji yang lebih sedikit. Kultivar Hamil yang ditanam dari biji memiliki umur berbunga yang lebih lama daripada kultivar yang ditanam dari pols. Hal ini mengakibatkan produksi bijinya lebih banyak (Gambar 2). Walaupun peneliti lain melaporkan hubungan yang positif antara umur berbunga dan produksi biji (Suroso \& Sodik 2016). Umur berbunga juga dapat dipengaruhi oleh berbagai faktor lingkungan seperti periode penyinaran, suhu, ketersediaan air, dan hara dalam tanah, senyawa kimia eksogen, mikrob, dan ketersediaan penyerbuk (Cho et al. 2017).

Nilai nutrisi kultivar Hamil yang ditanam dari biji dan pols disajikan pada Tabel 3. Nilai protein kasar (PK) kultivar yang ditanam dari pols cenderung lebih tinggi daripada kultivar yang ditanam dari biji, begitupun dengan nilai bahan keringnya. Sebaliknya, nilai serat kasar dan energi kultivar yang ditanam dari biji cenderung lebih tinggi daripada yang ditanam dari pols. Nilai PK kultivar Hamil masih dalam rentang nilai PK pada rumput benggala (Ramakrishnan et al. 2014), yakni nilai PK dari kultivar Panicum maximum antara 7,09 dan $11,20 \%$. Namun, data hasil nutrisi ini tidak dianalisis secara statistik sehingga tidak dapat dibandingkan antara kedua jenis benih yang ditanam.

\section{KESIMPULAN}

Karakter morfologi kultivar Hamil sebagian besar menunjukkan kesamaan antara kultivar yang ditanam dari benih berupa biji dan pols, Fenomena ini kemungkinan menunjukkan bahwa kultivar Hamil yang diteliti adalah bersifat apomiksis. Produksi benih, daya kecambah, dan bobot biji bernas kultivar yang ditanam dari biji lebih tinggi daripada yang berasal dari pols 


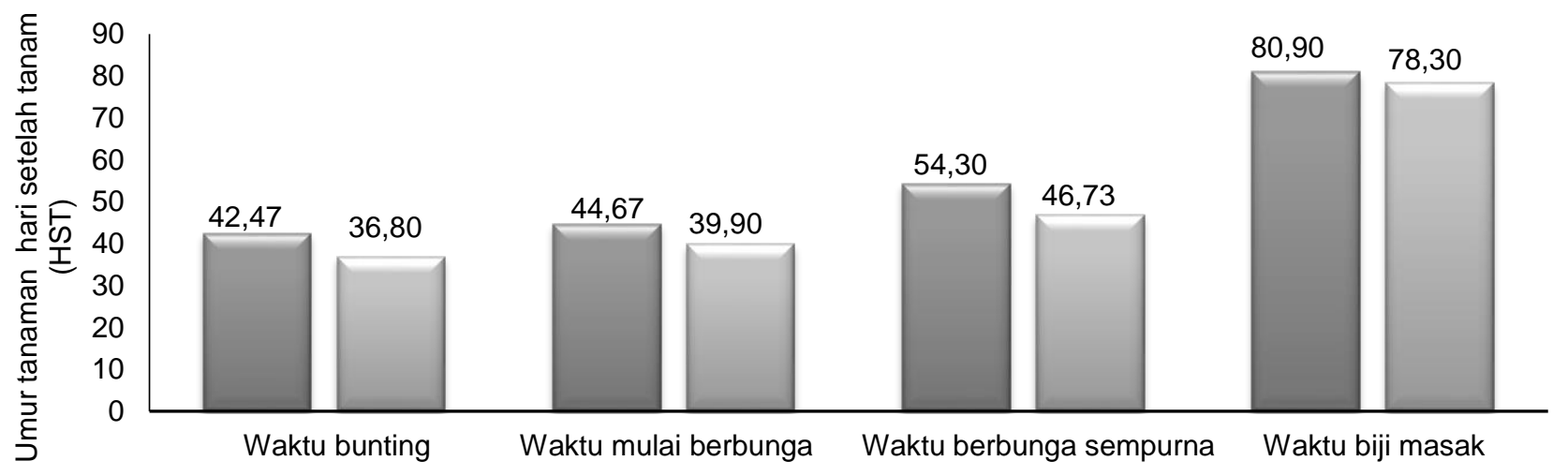

$\square$ Biji $\square$ Pols

Gambar 2 Umur tanaman waktu bunting, bunga kuncup, bunga sempurna, dan panen biji 3 kultivar rumput benggala.

Tabel 3 Nilai nutrisi kultivar Hamil yang ditanam dari biji dan dari pols umur 120 hari setelah tanam (HST)

\begin{tabular}{lcc}
\hline \multicolumn{1}{c}{ Karakteristik } & \multicolumn{2}{c}{ Kultivar Hamil } \\
\cline { 2 - 3 } & Biji & Pols \\
\hline Bahan kering (\%) & 7,78 & 8,92 \\
Protein kasar (\%) & 6,73 & 8,81 \\
Lemak kasar (\%) & 1,87 & 2,03 \\
EK (kal) & 4052 & 3959 \\
Serat kasar (\%) & 42,33 & 35,06 \\
Abu (\%) & 10,08 & 12,30 \\
Ca (\%) & 0,49 & 0,49 \\
P (\%) & 0,09 & 0,09 \\
\hline
\end{tabular}

sehingga benih biji disarankan untuk ditanam apabila ingin menghasilkan produksi biji yang tinggi. Perlu diteliti lebih mendalam perihal sitologi pada kantung embrio tanaman ini untuk menentukan secara pasti tentang sifat apomiksis pada kultivar yang diamati.

\section{DAFTAR PUSTAKA}

Al-Tahir FMM. 2014. Flag leaf characteristics and relationship with grain yield and grain protein percentage for three cereals. Journal Medicanal Plants Study. 2(5): 1-07.

Ali M, Hussain M, Khan MI, Ali Z, Zulkiffal M, Anwar J, Sabir W, Zeeshan M. 2010. Source-sink relationship between photosynthetic organs and grain yield attributes during grain filling stage in spring wheat (Triticum aestivum). International Journal of Agriculture and Biology. 12(4): 509-515.

Alvarenga CAF, Euclides VPB, Montagner DB, Sbrissia AF, Barbosa RA, De Araújo AR. 2020. Animal performance and sward characteristics of mombaça guineagrass pastures subjected to two grazing frequencies. Trop Grasslands-Forrajes Trop. 8(1): $1-10$.

Atherton DO. 1963. Personal communication. Brisbane(AU): Dep. Agric. and Stock, Brisbane.
Chen L, Nishimura Y, Umeki K, Zhang J, Xu C. 2015. Establishment of a Simple Plant Regeneration System Using Callus from Apomictic and Sexual Seeds of Guinea Grass (Panicum maximum). BBJ. 7(4): 183-190.

Cho LH, Yoon J, Gynheung A. 2017. The control of flowering time by environmental factors. Plant Journal. 90: 708-719.

Clements RJ, Henzell EF. 2010. Pasture research and development in northern Australia: An ongoing scientific adventure. Trop Grasslands. 44(4): 221230.

Conner JA, Ozias-Akins P. 2017. Apomixis: engineering the ability to harness hybrid vigor in crop plants. Methods in Molecular Biology. 1669: 17-34.

Hand ML, Koltunow AMG. 2014. The genetic control of apomixis: Asexual seed formation. Genetics. 197(2): 441-450.

Hare MD, Phengphet S, Songsiri T, Sutin N, Stern E. 2013. Effect of cutting interval on yield and quality of two Panicum maximum cultivars in Thailand. Trop Grasslands-Forrajes Trop. 1(1): 87-89.

Hare MD, Sutin N, Phengphet S, Songsiri T. 2018. Germination of tropical forage seeds stored for six 
years in ambient and controlled temperature and humidity conditions in Thailand Germinación de semilla de forrajeras tropicales durante seis años de almacenamiento bajo condiciones ambientales y condicio. Trop Grasslands. 6(1): 26-33.

Heidari H. 2017. Source-sink manipulation effects on wheat seed yield and seed germination characteristics. Biharean Biologist. 11(1): 33-36.

Hu C, Rao J, Song Y, Chan SA, Tohge T, Cui B, et al. 2020. Dissection of flag leaf metabolic shifts and their relationship with those occurring simultaneously in developing seed by application of non-targeted metabolomics. PLoS One. 15(1).

Jank L, De Lima EA, Simeão RM, Andrade RC. 2013. Potential of Panicum maximum as a source of energy. Trop Grasslands-Forrajes. 1(1): 92-94.

Kaushal P, Dwivedi KK, Radhakrishna A, Saxena S, Paul S, Srivastava MK, Baig MJ, Roy AK, Malaviya DR. 2018. Ploidy dependent expression of apomixis and its components in guinea grass (Panicum maximum Jacq.). Euphytica. 214(9): 4-6.

Madic M, Knezevic D, Paunovic A, Durovic D. 2016. Plant height and internode length as components of lodging resistance in barley. Acta Agric Serbica. 42(12): 99-106.

Ozias-Akins P. 2006. Apomixis: Developmental characteristics and genetics. Critical Reviews in
Plant Sciences. 25(2): 199-214.

Rahman M, Haque M, Sikdar B, Islam M, Matin M. 2014. Correlation Analysis of Flag Leaf with Yield in Several Rice Cultivars. Journal of Life and Earth Sciences. 8: 49-54.

Ramakrishnan P, Babu C, lyanar K. 2014. Genetic Diversity in Guinea Grass (Panicum maximum Jacq.) for Fodder Yield and Quality using Morphological Markers. International Journal of Plant Biology \& Research. 2(1): 1-4.

Suroso B, Sodik AJ. 2016. Potential and contribution of the results agronomic crop soybean (Glycine max L. Merrill ) on monoculture cropping system]. Agritrop Jurnal IImu-IImu Pertanian. 124-133.

Tambal HAA, Erskine W, Baalbaki R, Zaiter H. 2000. Relationship of flower and pod numbers per inflorescence with seed yield in lentil. Experimental Agriculture. 36(3): 369-378.

UPOV. 2006. International Union for The Protection of New Varieties of Plants. Ryegrass. Guidelines for The Conduct of Tests for Distinctness, Uniformity and Stability [Internet]. https://www.upov.int/ edocs/tgdocs/en/tg004.pdf

Walsh SR. 1959. Improved pastures will fatten cattle in far North. The Queensland Agricultural Journal. 85: 576-592. 